\title{
Assessing population perception and socioeconomic impact related to flood episodes in urban Côte d'Ivoire
}

\author{
Armand Ketcha Malan KABLAN ${ }^{1 *}$, Kouassi DONGO ${ }^{1,2}$, Gilbert FOKOU ${ }^{2,3}$ and \\ Mamadou COULIBALY ${ }^{4}$ \\ ${ }^{1}$ Université Félix Houphouët Boigny, Abidjan, Côte d'Ivoire (UFHB), 22 BP 582 Abidjan 22. \\ ${ }^{2}$ Centre Suisse de Recherches Scientifiques en Côte d'Ivoire (CSRS), 01 BP 1303 Abidjan 01. \\ ${ }^{3}$ Human Sciences Research Council (HSRC), 116-118 Buitengracht Street, Cape Town, 8001, South Africa. \\ ${ }^{4}$ University of Wisconsin Oshkosh, Department of Geography and Urban Planning, USA, 800 Algoma Blvd, \\ Oshkosh, WI 54901, USA. \\ ${ }^{*}$ Corresponding author; E-mail: kablan.malan@yahoo.fr; Tel: (+225) 08309085
}

\begin{abstract}
Urban flooding causes serious socioeconomic damages to cities worldwide. However, due to the lack of adequate sanitation and housing infrastructures, populations in developing countries are the most affected. This study sought to assess the population perception of the main issues around flooding, and the socioeconomic impact of flood-related damage in Abidjan, Côte d'Ivoire. Direct field observations, meteorological data analysis, a survey of land features and household interviews were therefore conducted. Poor design and mismanagement of drainage systems were seen as the primary causes of flooding, while the two main consequences reported were the displacement of affected populations and material damage. Residents seem to be aware of the causes and the potential consequences of flooding; however, they are lacking adequate prevention strategies and effective mechanisms of coping with the damage inflicted. For a more efficient flood management system, collaboration between authorities and affected populations is highly encouraged.
\end{abstract}

(C) 2019 International Formulae Group. All rights reserved.

Keywords: Developing country, drainage system, geographical survey, risk perception, urban flooding.

\section{INTRODUCTION}

Urban floods are among the most common and the most widely encountered natural hazards to life and property worldwide (Balica et al., 2012; Tingsanchali, 2012; Attingli et al., 2016). Evidence is accumulating that the occurrence and magnitude of floods and, hence, human exposure will increase in the coming years due to climate change (IPCC, 2014). With more than half of the human population living in urban areas, the phenomenon of urban flooding is becoming a particular concern (Nasiri and

Shahmohammadi-kalalagh, 2013).

In the last decade, urban floods have affected most parts of the world, including Africa, Asia, Europe and the US. Flooding occurs in the least developed nations as well as in the most developed countries of the world (UNISDR, 2002). However, the causes and effects of flood in developed countries seem to differ from those in resource-poor settings (Drabo and Mbaye, 2011). In developed countries where urban areas are often well-planned and where infrastructures 
and drainage systems are relatively well designed, the occurrence of flood is mostly associated with natural hazards and climate change-related effects such as storm surges, earthquakes and flash floods. The same applies to developing countries; however, poor infrastructures and drainage systems further increase the degree of exposure and vulnerability of at-risk populations (Temgoua et al., 2009; Parkinson et al., 2007). Moreover, in Sub-Saharan Africa where approximately $72 \%$ of urban inhabitants are live in slums (UN-Habitat, 2008), the consequences of urban floods are likely to be worsened by the lack of adequate housing (Zhou, 2014). Unplanned growth and development are factors that increase the risk of flooding in urban areas as flood protection structures are more likely to fail under extreme hydrological weather conditions (WHO, 2015).

Many strategies have been developed to adapt to the effects of flood including flood risk transfer through insurance, implementation of structural flood control measures, empowerment of laws related to natural disaster and the establishment of risk perception and warning systems (IPCC, 2014; Nikolaou et al., 2014). Previous research suggests that the impact of flooding is closely related to how people manage to adapt to this phenomenon. Along the same lines, the United Nations reported that in developed countries, the economic impact of flood is on the rise whilst the number of people affected by flood remains steady (UNISDR, 2002). In contrast, in least developed countries, both economic impact and the number of affected communities are on the rise (UNISDR, 2002). The increasing economic impact of flood is directly related to the high investments that are often undertaken in wealthy urban areas. However, the reason for the increasing number of people affected by flood in developing countries remains undefined and may relate to sub-optimal flood management strategies aspects in population behavior and perception of urban flooding or general urban expansion processes. Understanding how urban residents are affected by flood, how they perceive the risk and what factors worsen flooding in urban areas could be an important step toward designing more resilient cities.

Cocody is one of the wealthiest municipalities in Abidjan, Côte d'Ivoire and one of the most urbanized areas in West Africa. The apparent wealth of the municipality is not reflected by the policies that are put in place to fight floods therefore a relatively high proportion of its population is affected by the phenomenon. In fact, Cocody recorded the highest number of threatened individuals (i.e. > 40,000), compared to the other districts, in the aftermath of flooding events in Abidjan in 2014 (OCHA, 2014). Each rainy season is characterized by a number of deaths and infrastructural damage. According to the Office for the Coordination of Humanitarian Affairs (OCHA) an average of 13 flood-related deaths per year were recorded in Abidjan from 2009 to 2014 (OCHA, 2014). Even though statistics of the population affected by floods exist (Jha et al., 2011; OCHA, 2014), the way flood impacts on the socioeconomic life of the residents of Cocody remains poorly understood. In addition, there is no local information on how the affected population perceives flood risk therefore it is difficult to develop appropriate mitigation measures. The objective of this study was to evaluate the perception of the atrisk population of Cocody regarding the main flood-related issues and to assess the socioeconomic impact of flood episodes on residents in order to develop an efficient flood management system that will benefit the community.

\section{MATERIALS AND METHODS Study area}

The research was conducted in Cocody, one of ten districts of the city of Abidjan located in the eastern side of the city, between latitude $5^{\circ} 18^{\prime}$ and $5^{\circ} 26^{\prime} \mathrm{N}$ and longitude $3^{\circ} 53^{\prime}$ and $4^{\circ} 1^{\prime}$ W. The municipality of Cocody covers an area of $144.59 \mathrm{~km} 2(\sim 21 \%$ of the total size of Abidjan). It borders the municipality of Abobo in the north, the Ebrie lagoon in the south, the municipality of Adjamé in the west and the town of Bingerville in the east 
(Figure 1). According to the 2014 national census, Cocody has 447,000 inhabitants, which is $10.2 \%$ of the total population of Abidjan (RGPH, 2014). It is the third most populated municipality of Abidjan after Yopougon (23.7\%) and Abobo (23.3\%).

\section{Documentary research}

To appreciate the socioeconomic impact of floods on the population of Cocody, the current knowledge of this phenomenon and the spatial variability of flood implications, an extensive systematic review of the literature was undertaken. We developed a comprehensive search strategy to first identify articles available in Google Scholar database with no restriction on publication date of the article. References included various aspects of flood (risk, vulnerability, perception and adaptive measures) in tropical African cities including Abidjan. Relevant references were manually selected. Secondary data were collected through international (OCHA, PNUD), national (BNETD, CCT, SODEXAM and INS) and local institutions (mayor and key contacts among local agents). They were used for the acquisition of numerical data (e.g. master map of Cocody, frequently flooded areas last ten years in Abidjan, climate data and national census data) or for facilitating the administration of questionnaires developed for the population survey. Data were stored and integrated into databases for further investigation.

\section{Climate data analysis}

In order to identify periods when flood events are most likely to occur, 40 years (1973-2012) of cumulative monthly rainfall data were analyzed in Excel. Consequently, the surveys were undertaken in periods with highest flood risk in order to detect flood hot spots in the municipality of Cocody and to get up-to-date information on the flood issues from the residents.

\section{Socio-environmental survey}

Two types of socio-environmental surveys were conducted during this study. A geographical survey was carried out for environmental data collection, whereas a household survey was undertaken to obtain the socioeconomic information. The OCHA map produced in 2014 (OCHA, 2014) providing flood-prone areas in Abidjan was used as a baseline map for both surveys. Based on that map, in 29 of the defined 34 municipality areas of the municipality of Cocody that are commonly affected by flood, related environmental problems have been identified. Five municipality areas were not concerned by the survey as they were not located in any of the floodplains. Thus, both geographical and household surveys concerned only the affected 29 municipality areas. In order to obtain an accurate idea of the environmental problems to be addressed, the technical approach for the collection of environmental data was started with visits to all selected areas for direct field observations. Accordingly, three visits for direct field observations during the rainy season of June 2015 preceded the actual geographical investigation that was carried out in the same month. The geographical investigation covered all the municipality areas of Cocody to confirm the flood-prone areas as defined by OCHA in 2014 and to verify whether some areas have been left out or should be excluded, to identify the flood hot-spot areas of the municipality and to check for existing flood-related environmental problems. Floodprone areas were visited with a digital camera to capture images of environmental problems discovered, a notebook to write down all observed problems and a GPS receiver to record the precise location of the discovered environmental problems or flood hotspot areas. After compiling the observations of the field visit to obtain an important information base for subsequent investigations, a geographical survey was carried out.

The geographical survey was conducted to obtain the three main environmental parameters: household waste, drainage systems and the state of the roads. The survey was conducted after the first heavy shower in June 2015 during the main rainy season. The questions took into account the concepts related to flood and sanitation deficits in order to enable an accurate 
description of the current state of environmental parameters that contribute to flooding and impact on the lives of the population. To describe the sanitation status of flood-affected areas and to evaluate the dynamics of the corresponding waste during rainfall and flooding, household waste was selected as the most relevant environmental indicator. Both the volume of the waste pile and its distance to the closest drainage system were measured. Following the household waste survey, the investigation focused on the state of road infrastructures to assess their accessibility. The last measured parameter was the drainage system which was checked for the presence of household waste and its ability to channel storm water. The measurements of the environmental parameters were recorded on a pre-set outcome form that was designed based on information obtained from earlier field visits and preliminary observations of the characteristics of environmental parameters. A GPS receiver was used to determine the coordinates of different points of interest and a $50 \mathrm{~m}$ metric tape was used for estimating the volume of household waste piles and for measuring the distance from the waste pile to the closest drainage system. Three trained investigators visited and assessed all selected areas in the Cocody municipality, confirming flood-prone areas on populated floodplains.

Semi-structured interviews with the keys officials of municipality of Cocody, namely the municipal authorities (mayor) and community leaders (key contact among local agents and religious leaders) were subsequently conducted in July 2015. The interviews assessed their knowledge of flooding, their perceptions of the phenomenon of flooding in their respective jurisdictions, their coping strategies and their recommendations to improve the well-being of the populations with regard to flood.

The household surveys were carried out during the rainy season after the geographical data collection in July 2015 and were based on one-to-one interviews at the respondent's residence. In this particular set up, the interviewer assisted the interviewee to complete the questionnaire, if necessary, to ensure equal capacity to respond among the interviewees from randomly selected households (Statistics Canada, 2010). Owing to the variety of social classes involved in the study, this technique was critically important, especially where respondents showed a low level of literacy. The survey was conducted in each of the 29 defined municipality areas and the spatial selection of households was performed using transect method (selection made at regular intervals) over the entire area of interest. The questionnaire was administrated to the heads of the household or their representatives, and it was ensured that all respondents were at least 18 years old. The initial part of the investigation was structured around the residents' general perceptions of flood. Furthermore, their impressions of flash floods, their experiences with floods being eye-witness and their coping capacities in relation to sanitation deficits were documented. Five trained interviewers visited all selected municipality areas in Cocody to complete the questionnaires.

\section{Sampling methods}

To capture urban inhabitants' perceptions and practices related to the impacts of flooding, semi-structured interviews with local officials and household surveys were carried out using an interview guide and a questionnaire that took climate variability into account. Concerning the household survey, respondents were randomly selected among the Cocody residents. The method adopted here is a stratified simple random sampling with proportional distribution (Statistics Canada, 2010). In the absence of accurate data on the total number of households in the municipality of Cocody, sampling was based on the size of the population. Taking into account that the questionnaire was administrated to the head of household or their representative, the estimated sample size was based on Equation 1.

$$
n_{1}=\frac{z^{2} \beta(1-\beta)}{e^{z}}
$$

Equation 1 provides the initial size of sample of the population to be questioned $\mathrm{n}_{1}$ based on the desired level of confidence $\mathrm{Z}$ 
(with a level of confidence of $95 \%, Z=1.96$ ), the permitted margin of error in statistical risk $\mathrm{e}(\mathrm{e}=5 \%)$ and the estimated population ratio $\mathrm{p}$ (in our case, the estimated ratio was not available, thus $\mathrm{p}=0.5$ ).

The initial sample size of Equation 1 was adjusted taking into account population size leading to Equation 2:

$n_{2}=n_{1} \frac{N}{N+n_{1}}$

Equation 2 expresses the adjusted sample size of the population to be interviewed $n_{2}$ based on the total size of the population of the municipality of Cocody $\mathrm{N}$ and the initial sample size $\mathrm{n}_{1}$. In this study, the sampling is based on the 2014 census, according to which the size of the Cocody population $(\mathrm{N})$ is 447,055 . Thus, based on the formula derived from Statistics Canada, a minimum sample of 384 inhabitants is representative of the population of Cocody. However, anticipating incomplete forms, a percentage of $80 \%$ of respondents was expected for each interviewer. Thus, the number of respondents becomes (Equation 3):

$$
n=\frac{n_{2}}{r}
$$

Equation 3 provides the size of the population to be interviewed, $n$, based on the percentage of expected respondents, $r$, and the adjusted size of the population to be interviewed, n. Thus, according to Statistics
Canada, the total population to be interviewed corresponds to 480 inhabitants. This sample was not stratified. The spatial distribution of respondents per municipality area was done by linking the proportion of the size of flood predefined areas that are inhabited to the population of each municipality area. The interviewed households were selected across all concerned municipality areas by applying Equation 4.

$$
n_{n}=\frac{x i}{s} n
$$

Equation 4 calculates the size of the population to be interviewed per municipality area nh based on the size of the flood inhabited municipality area $\mathrm{Xi}$, the total size of flood inhabited predefined areas of Cocody $\mathrm{s}$ and the total size of the population to be interviewed n'. However, for greater representative power of the sample (quality control) and with the available means, several corrections and considerations were made when using the transect method. This increased the number of households of some municipality areas to be questioned and therefore the total sample size to 584 households. According to Statistics Canada, the selected data collection method should give a sufficiently high turnout with sufficiently complete and accurate data (Statistics Canada, 2010).

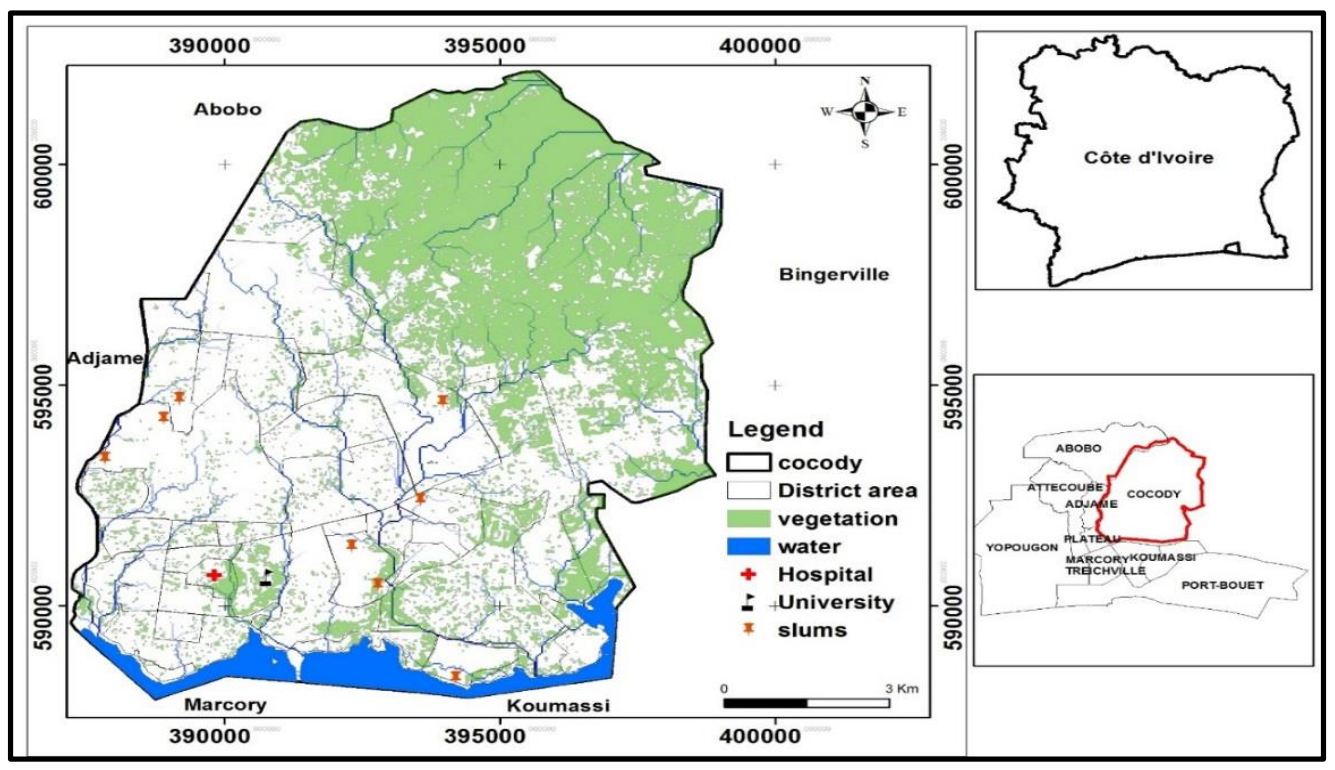

Figure 1: Localization of the Cocody municipality. 


\section{RESULTS}

\section{Climatic factors and flood hotspots}

The distribution of rainfall in Abidjan throughout the year defines two rainy seasons as presented in Figure 2. The first rainy season runs from April to July with a total rainfall amount of $1148.59 \mathrm{~mm}$, representing approximately two thirds of the total annual precipitation. During this main rainy season, the annual risk of flooding in Cocody is highest, especially in some municipality areas known as flooding hot spots. Flood-prone municipality areas are Palmeraie, Bonoumin, Riviera-Sideci and Angre (Figure 3). May and June appear to be the most critical months, particularly June, when the average annual peak of $524.81 \mathrm{~mm}$ of precipitation is reached. June alone accounts for more than $29 \%$ of the total annual rainfall. The second rainy season of the year starts in October and ends in November, with a total combined precipitation of $291.55 \mathrm{~mm}$ corresponding to $16.3 \%$ of total annual precipitation. Floods can occur during this period but not as frequently as it is observed for the first rainy season. The rainy seasons are separated by two dry seasons. The first dry season starts in December and ends in March and is the warmest period of the year. Precipitation is often observed, accounting for $13.5 \%$ of the total annual rainfall. The second dry season starts in August and ends in September. Although there is a generally low risk of floods during the dry seasons isolated flood episodes are becoming more common due to unexpected rainfall.

\section{Environmental characteristics of flood episodes in Cocody}

Environmental issues reported after flood episodes in the municipality of Cocody concerned waste management, the drainage system and the state of road infrastructures (Figure 4). Among the 29 municipality areas surveyed, a proportion of $41.4 \%$ was concerned with those flood related environmental problems.

Regarding waste management, 75 unplanned waste dumping sites were reported throughout the municipality belonging to ten different municipality areas (Figure 4b). The 75 unplanned waste dumping sites corresponded to a volume of $1361.6 \mathrm{~m}^{3}$ and $64 \%$ were close to a drainage system (i.e. < $5 \mathrm{~m})$. The municipality areas of Bonoumin, Angre, Anono and Palmeraie together shared the biggest volume $(92.0 \%)$ of this waste with $111.6 \mathrm{~m}^{3}, 131.8 \mathrm{~m}^{3}, 922.0 \mathrm{~m}^{3}$ and $92.2 \mathrm{~m}^{3}$.

Evaluation of the drainage system revealed that 95 storm water channels across 12 municipality areas were not working properly. A proportion of $34.7 \%$ of these drainage systems were found to be illegal with the highest ratio found in Anono (18 illegal out of 23), one of the poorer municipality areas of Cocody. All drainage systems that were reported across the 12 municipality areas were either blocked (73.7\%), broken $(29.5 \%)$, cracked $(43.2 \%)$, or obstructed by sand $(100.0 \%)$ (Figure $4 a)$. They were often found subject to acts of vandalism $(41.0 \%)$ or to mixed solids and liquid wastes dumped by residents.

The assessment of road infrastructures demonstrated that 61 roads across 11 municipality areas of Cocody were degraded and that a proportion of $4.5 \%$ of these roads were inaccessible and/or out of service. All roads assessed were in poor condition (e.g. showing cracks), were covered by sand, blocked, abandoned or impractical in other ways (Figure 4c).

\section{Household characteristics}

More than $30 \%$ of the interviewees were heads of households. The chiefs of families were generally the sole earners (48.7\%), and the expenses of a given household were shared by other workers $(57.4 \%)$. The majority of participants were not insured at all (80.0\%) and only a small minority possessed flood insurance $(2.0 \%)$. Among the participants of the survey, $40.6 \%$ were women, $49.8 \%$ of the respondents were between 18-35 years old and more than $89.0 \%$ are literate. All members of the households assessed had been living in their houses for at least one year and the average number of people per household reported was 6 , ranging from 2 to 27. 


\section{Residents perception and adaptation measures regarding flood in Cocody}

Prior to the investigation on flood perception, residents were asked whether they were acquainted with the concept of flooding. They all responded positively and indicated appropriate baseline knowledge for conducting the interviews. Eight days were necessary for the completion of the surveys and each interview lasted 16 minutes on average. Moreover, more than $59 \%$ claimed to have been directly concerned with flood events in the past. According to their understanding, heavy rainfall leads to flooding due to the weakness of the drainage system $(52.1 \%)$, the steepness of the affected regions $(9.1 \%)$ or both the topography and the weakness of the drainage system $(38.8 \%)$. With regard to Cocody dwellers perception of the intensity of the rainfall, $60 \%$ acknowledged having observed an increase in the intensity of rainfall over the past ten years and thought that their living environments could be affected by this increase. In relation to this issue, respondents were specifically referring to past flood events $(61.7 \%)$ or the absence or weakness of the drainage system (35.3\%). A proportion of $29.1 \%$ of the household-representatives interviewed were aware that their houses were located in floodprone areas. Among them, $55.1 \%$ believed that their direct environment could be affected during a flood event. Almost all households (95.5\%) believed that floods were dangerous and constitute a threat to their security. Moreover, $81.2 \%$ were anxious about the quality of flood water, thinking that it was dirty and that it would drain waste into houses and, thereby, trigger some diseases. Regarding their experience with floods, all householdrepresentatives seemed to have witnessed the phenomenon at least once in their lifetimes. Furthermore, $41.5 \%$ stated to have observed that the frequency of flood episodes is increasing and that floods can occur anytime during an excess rainfall event (28.8\%). Only $2.6 \%$ perceived the frequency of floods in the past decade to have decreased.

Evaluation of the residents practices for coping with flooding revealed that $73.1 \%$ did not know what to do in case they were struck by flash floods, wondering whether to leave their residences or to stay. A proportion of $19.5 \%$ and $6.2 \%$ of the households responded that they would temporarily move to a relative's or a friend's home, respectively. Only $1.2 \%$ would have been willing to relocate permanently. With regard to adaptation strategies, $18.5 \%$ of households used home dikes to protect against flooding while $7.2 \%$ used relocation as strategy. More than $70 \%$ did not leave or did not do anything to prevent their houses from being affected.

The flood management measures implemented by State authorities is differently appreciated by the residents. Only 3\% of flood victims confirmed that they were assisted by the government.

\section{Socioeconomic impacts of floods on households}

The socioeconomic impact of floods on the residents of Cocody ranges from displacement and dislocation of families to loss and destruction of goods. Among the 584 households surveyed, $198 \quad(34.0 \%)$ were affected by flooding. Of those, $16.0 \%$ of all families moved permanently from their houses owing to the recurrent nature of flooding episodes in their living environment. The municipality area of Bonoumin recorded the highest number of displaced families with $34.4 \%$ of households being affected by flooding. A total of 12 families were dislocated due to recurrent flood events. Individual movements were also observed by household members that left the family in their residential houses temporally or that relocated permanently into a rental house. In 2 families, each member of the family relocated separately, using his or her own means and social networks. Flooding also has caused loss and destruction of goods. More than $57.0 \%$ of the affected households have either lost important documents or clothes or they have seen their electronic devices destroyed and their sanitation utilities damaged.

To respond to the various problems induced by flooding, 13 households have reported to have spent money on repairs. They 
spent an average of 175,000 FCFA (\$ 350) to relocate or to replace damaged goods. Only $9.0 \%$ of affected households called for government assistance and $49.0 \%$ of households turned to their relatives for help. To mitigate recurrent events of flooding, people have reported several strategies, including the building of fences to prevent runoff from entering their properties. An example of these dike-like structures that are built at the gate or at any points where runoff may flow into the house is represented in Figure 3c.

The Ivorian government initiated an eviction and demolition campaign to destroy structures and infrastructures obstructing the paths of storm water. Despite the fact that the government destroyed many buildings in the municipality of Cocody, only $2.9 \%$ of households have been affected by the campaign.

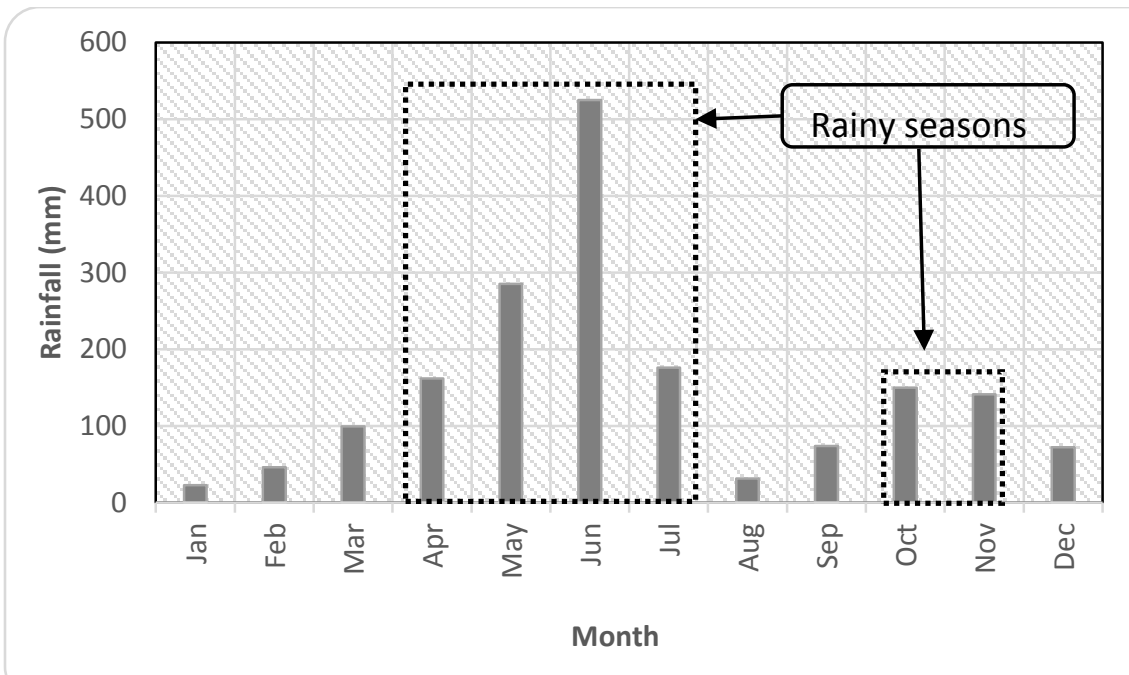

Figure 2: Monthly rainfall variation in Abidjan from 1973 to 2012.

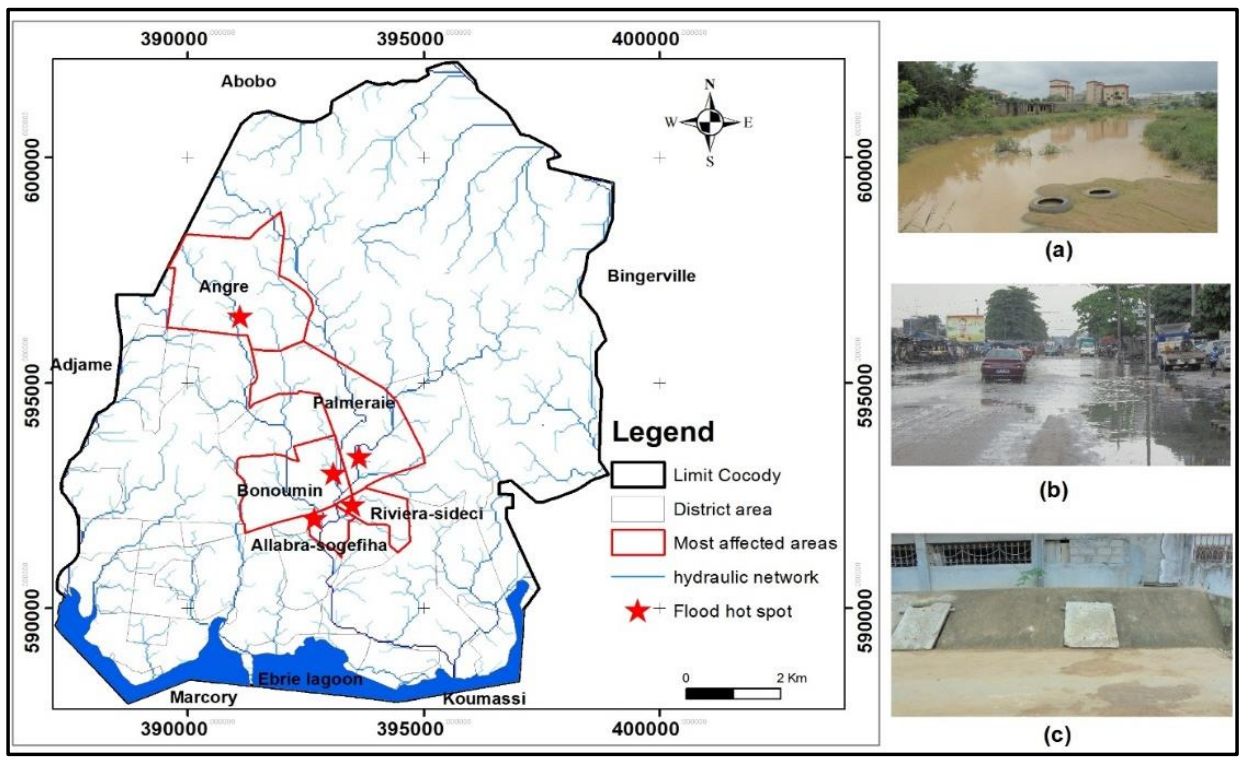

Figure 3: Flood hot spots and adaptive measure; (a) flooded abandoned road in the Palmeraie municipality area; (b) flooded road in the Palmeraie municipality area; (c) fence against flood used as adaptive measure in the Bonoumin municipality area. 


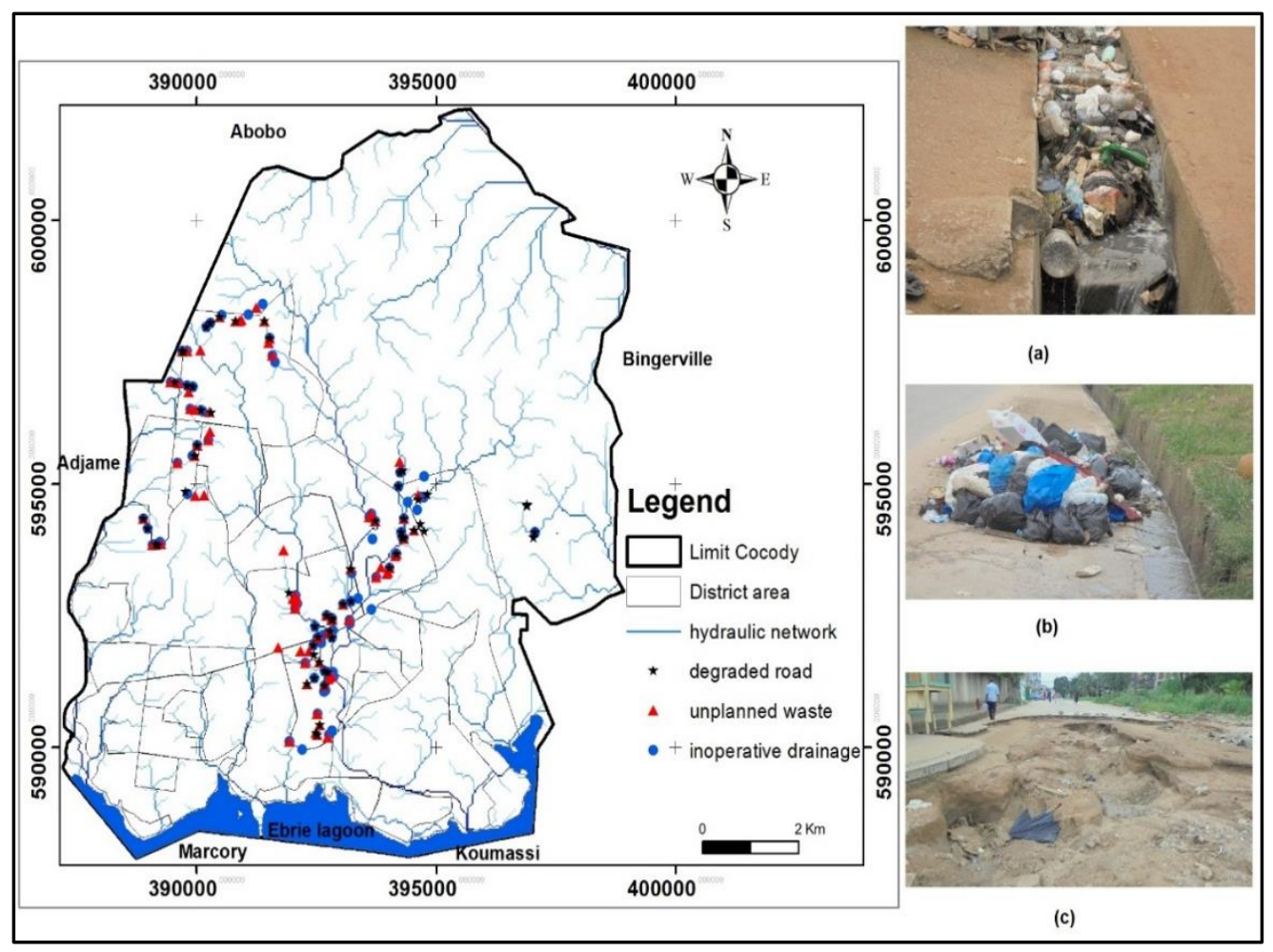

Figure 4: Localization of flood related environmental issues in Cocody.

\section{DISCUSSION}

With two rainy seasons Cocody represents the typical characteristics of the climate that prevails in the Gulf of Guinea in West Africa (Lucio et al., 2012; Sultan and Janicot, 2000). However, the second rainy season in Côte d'Ivoire has demonstrated an increase in the frequency of flooding events in the last decade which may be indicative of a wider future trend. Seasonal shifts have been observed in Côte d'Ivoire as a consequence of global climate change which are blurring the lines between rainy and dry season and which render the occurrence of off-season floods more likely.

The other main reason why previous low-risk periods (i.e. April and September for Côte d'Ivoire) are becoming more affected by floods is poor adaption to increasing urbanization (Douglas et al., 2008). Rapid urbanization has taken place in Abidjan in the last decade without adjusting for environmental factors (e.g. changing climate conditions and flood hazards) which might partially explain why four relatively wealthy and well-designed municipality areas in Cocody with a supposedly high interconnected network of drainage systems (i.e. Angre, Bonoumin, Palmeraie and RiveraSedeci) represent flood hot spots. In fact, studies highlighted that drainage systems in most developing urban areas are not designed to carry storm water (Parkinson, 2002; Parkinson et al., 2007). Natural drainage pathways and floods are often not taken into account when planning for a drainage system (Parkinson, 2002), even though they are mostly located in humid tropical regions where rainfall is critically linked to flooding during certain periods of the years.

Our study revealed three socioenvironmental key problems that impact on the wellbeing of Cocody's residents - the lack of waste management, poorly maintained drainage systems and road infrastructure problems. Waste dumping sites were spotted 
in flood impacted municipality areas as well as non-flood areas which shows the lack of waste management systems across the municipality of Cocody, especially in municipality areas where floods are more recurrent. The absence of a formal waste management system is characterized by uncontrolled waste dumping which renders it difficult to measure the extent of the problem and to adapt managerial strategies (Driscoll, 2011; Soro et al., 2010). In addition, a significant number of waste dumping sites were found to be less than $5 \mathrm{~m}$ away from the closest drainage system. The smaller the distances between the waste piles and the drainage systems the higher is the probability that the waste will be channeled into the drainage system and clog it, and hence force water out of its regulated path during heavy rains. Our study has, indeed, demonstrated that more than two thirds of all drainage systems assessed were clogged with waste and sand. These problems seem to be common to most developing countries, especially those in tropical humid West Sahara Africa, such as Ghana and Benin, where flooding appears to be a recurrent challenge for stakeholders (Lamond et al., 2012). Previous research showed that in many cities around the world poor solid waste management can negatively impact urban drainage (UN-Habitat, 2008). The same issue has been highlighted by Douglas et al. (2008) who showed that the canals in poor areas of African cities are often obstructed by silt and urban debris causing flooding, particularly when houses are built close to the channels. This problem can lead to recurrent urban flooding, as it is already seen in many African cities including Dakar and Banjul (Jacobsen et al., 2013). Furthermore, waste can be carried into houses, during flood events, and impact on the wellbeing of their inhabitants (Parkinson, 2002). The $41 \%$ of observed illegal house connections to drainage systems suggest that there are uncontrolled (unregulated and/or without protection) drainage systems to some extent. This reality clearly shows a deficit in the waste water management system. Unlike in developed countries, waste management seems to be one of the lead causes of flooding in developing countries, especially those in humid tropical regions. One of the reasons for the deficit in waste management may be the rapid urbanization that is taking place in large cities like Abidjan and the lack of adjustment to the subsequent growing urban population. As floods are mostly due to an overflow of drainage systems, dirty water derived from these channels could reach households and lead to negative health effects related to floods, as highlighted by previous studies (Lamond et al., 2012). The current suboptimal situation with regard to waste management and drainage systems is further exacerbated by the degradation of road infrastructures we have observed. The crevasses seen on the roads illustrate the force of the flood water currents and demonstrate that they are not adapted to the regional weather conditions. The roads often remain unrepaired for a long period after the flood event has taken place which can challenge any efforts for structural/managerial improvement and which, in cases of an emergency, could hinder an appropriate response.

We found that flood has caused the displacement of $16 \%$ of the affected households which is similar to the numbers reported from other tropical African urban areas, such as the Ado-Ekiti metropolis in Nigeria and Dakar in Senegal (Aladelokun and Ajayi, 2014; Sané et al., 2015). Displacement appears to be one of the oldest and most applied coping strategies for dealing with natural hazards (Kolmannskog, 2008) and is practiced by affected urban citizens in both industrialized and developing countries. The displacement of families relies on available means for such a relocation and adequate social structures to accommodate the victims. Consequently, putting in place a wellstructured flood management strategy may help avoiding the displacement of families and individuals.

Many citizens of Cocody were affected by a loss of important documents and damage of materials. However, the majority of 
residents were not insured, and those with insurance were not covered for flood damage. Given the circumstances it seemed appropriate to consider flood insurance as loss transfer and to include it into the flood risk management tools, especially in tropical humid areas where heavy seasonal precipitations occur. The concept of flood insurance as risk transfer tool exists in most developed countries affected by flood, such as England (Penning-Rowsell, 2015; Surminski and Eldridge, 2015) and should also be implemented in developing countries.

$$
\text { Every single interviewee }
$$
acknowledged knowing what flooding is and to had already witnessed its effects. This knowledge might be explained by the advanced levels of education of the dwellers of the municipality areas assessed. The interviewees stated the drainage systems as primary cause of floods, which is in line with the field observations. They further named topography as one of the lead causes of flooding, which is in line with previous reports (Akintola, 1994; Douglas et al., 2008; Balica et al., 2009) but has not been found to be a major issue in the current Cocody setting.

In our study, one-third of all households assessed declared being affected by floods in one way or another. In spite of the municipality authorities' declaration of their intent to help victims recover from every seasonal flood events, $70.2 \%$ of the victims contested having received any help from the government. This testimony leads to the understanding that the help is neither wellplanned nor well-executed since affected areas seem ultimately neglected. Although there is a warning plan called "Plan ORSEC" (an Emergency Rescue Plan), the striking majority of the respondents (> 95\%) declared that they have not received any flood information before being affected by such an event. Even when they received warnings, they were not taught what to do, therefore, the ORSEC plan seems to be ineffective. The sum of deficits emphasizes the need for an early warning system, such as the sensor networks installed in flood defenses, which was developed by Krzhizhanovskaya et al. (2011).
Although flood hazards are natural phenomena that are difficult to predict, damages and losses are social aspects and should therefore be manageable (Mendel, 2006; Abou et al. 2018).

The household survey relies on the capacity of respondents to remember past events, which is an inherent limitation. However, in our study, the combination of field observation and household survey reduced the subjectivity related to the questions. Also, the survey took place only few days after the flood events.

\section{Conclusion}

The current observations reemphasize the fact that the environmental issues that aggravate flood occurrence appear to be common to most developing countries across the globe. Problems result consistently from sub-optimal waste management, poorly designed drainage systems and poor road infrastructure. It is therefore paramount to address these three key indicators when planning for long term and impactful flood management strategies.

People seem to have a realistic perception of the risks related to flood; however, our results suggest a lack of communication between the administrative authorities and the population. Increasing exchange between them may contribute to alleviate some of the socioeconomic consequences around flooding. Proper communication should result in improved maintenance of drainage networks and roads and greater social support to displaced/dislocated families and individuals. $\mathrm{We}$, therefore, recommend putting in place an observatory committee for a better follow-up of the actions that are undertaken to ensure the adaptation of the flood victims.

\section{COMPETING INTERESTS}

The authors declare that they have no competing interests.

\section{AUTHORS' CONTRIBUTIONS}

AKMK and KD conceptualized and designed the research. AKMK collected data 
from various sources, performed the assessment and drafted the original manuscript. KD, GF and MC provided skills development, comments and suggestions during data generation, analysis, and results interpretation. All authors helped improve the different versions of the manuscript. They also read and approved its final draft.

\section{ACKNOWLEDGEMENTS}

This research received no specific grant from any funding agency in the public, commercial, or not-for-profit sectors. The authors attest that no funds were received for covering the costs to publish in the journal. The authors would like to thank the Université Félix Houphouët Boigny, Abidjan, Côte d'Ivoire (UFHB) from which this work is derived. They acknowledge the collaboration of the Centre Suisse de Recherches Scientifiques en Côte d'Ivoire (CSRS). We are also grateful to the collaboration of the West African Science Service Center on Climate Change and adapted Land Used (WASCAL, Abidjan, Côte d'Ivoire). Finally, the authors would like to express their gratitude to the population and authorities of Cocody municipality for their support and collaboration during data collection.

\section{REFERENCES}

Abou M, Yabi I, Yolou I, Ogouwale E. 2018. Caractérisation des systèmes de production sur les sites d'aménagements hydro-agricoles dans le doublet DangboAdjohoun au sud du Bénin. Int. J. Biol. Chem. Sci., 12(1): 462-478: DOI: https://dx.doi.org/10.4314/ijbcs.v12i1.36

Akintola FO. 1994. Flooding Phenomenon. In Ibadan Region, Filani MO, Akintola FO, Ikporupo CO (Ed). Rex Charles Publications: Ibadan; 2440-2255.

Aladelokun AO, Ajayi CF. 2014. An appraisal of the socio-economic impacts of urban flood in Ado - Ekiti Metropolis in Ekiti State. International Journal of Asian Social Science, 4(10): 1027-1034. http://www.aessweb.com/pdf-files/ijass2014-4(10)-1027-1034.pdf
Attingli Ah, Vissin Ew, Ahouansou-Montcho S, Zinsou Lh, Laleye PA. 2016. Perception endogène de l'influence des changements climatiques sur la pêche dans la basse vallée de l'Ouémé (Sud Bénin). Int. J. Biol. Chem. Sci., 10(5): 1998-2014.

DOI: http://dx.doi.org/10.4314/ijbcs.v10i5.5

Balica SF, Douben N, Wright NG. 2009. Flood vulnerability indices at varying spatial scales. Water Science and Technology, 60(10): 2571-2580. DOI: 10.2166/wst.2009.183

Balica SF, Wright NG, Meulen VDF. 2012. A flood vulnerability index for coastal cities and its use in assessing climate change impacts. Natural Hazards, 64( 1): 73-105. DOI: 10.1007/s11069-0120234-1

Douglas I, Alam K, Maghenda M, McDonnell Y, McLean L, Campbell J. 2008. Unjust waters: climate change, flooding and the urban poor in Africa. Environment and Urbanization, 20(1): 187-205. DOI: 10.1177/0956247808089156

Drabo A, Mbaye LM. 2011. Climate Change, Natural Disasters and Migration: An Empirical Analysis in Developing Countries. Institute for the Study of Labor, Bonn, Germany, pp. 1-32.

Driscoll D. 2011. Introduction to Primary Research: Observations, Surveys, and Interviews. In Writing Spaces: Readings on Writing, Lowe C, Zemliansky P (ed). San Francisco, California; 153-174.

IPCC. 2014. Summary for Policy Makers. In Climate Change 2014: Impacts, Adaptation, and Vulnerability. Part A: Global and Sectoral Aspects. Contribution of Working Group II to the Fifth Assessment Report of the Intergovernmental Panel on Climate Change, Field CB, Barros VR, Dokken DJ, Mach KJ, Mastrandrea MD, Bilir TE, Chatterjee M, Ebi KL, Estrada YO, Genova RC, Girma B, Kissel ES, Levy AN, MacCracken S, Mastrandrea PR, White LL (ed). Cambridge University 
Press: Cambridge, United Kingdom and New York; 1-32.

Jacobsen M, Webster M, Vairavamoorthy K. 2013. The Future of Water in African Cities - Why Waste Water? (1st ed). The World Bank: Washington D.C.

Jha A, Lamond J, Bloch R, Bhattacharya N, Lopez A, Papchristodoulou N, Bird A, Proverbs D, Davis J, Barker R. 2011. Five Feet High and Rising Cities and Flooding in the 21st Century (1st ed). The World Bank: Washington D.C

Kolmannskog VO. 2008. future floods of refugees: A comment on climate change, conflict and forced migration (1st ed). Norwegian Refugee Council: Oslo, Norway.

Krzhizhanovskaya VV, Shirshov GS, Melnikova NB, Belleman RG, Rusadi FI, Broekhuijsen BJ, Gouldby BP, Lhomme J, Balis B, Bubak M, Pyayt AL, Mokhov LL, Ozhigin AV, Lang B, Meijer RJ. 2011. Flood early warning system: Design, implementation and computational modules. Procedia Computer Science, 4(2011): 106-115. DOI:

https://doi.org/10.1016/j.procs.2011.04.0 12

Lamond J, Bhattacharya N, Bloch R. 2012. The role of solid waste management as a response to urban flood risk in developing countries, a case study analysis. In Flood Recovery Innovation and Response, Proverbs D, Mambretti S, Brebbia C, De Wrachien D (ed). WIT Press: Southampton; 193-205.

Lucio PS, Carlos L, Molion B, Elisa C, Valadão DA, Conde FC, Ramos AM, Melo DD. 2012. Dynamical Outlines of the Rainfall Variability and the ITCZ Role over the West Sahel. Atmostpheric and Climate Sciences, 2(3): 337-350. DOI: $10.4236 /$ acs.2012.23030

Mendel, G. 2006. Climate Change, Urban Flooding and the Right of Urban Poor in African: Key Findings from Six African Cities. Action Aid International: London - Johannesburg.
Nasiri H, Shahmohammadi-kalalagh S. 2013. Flood vulnerability index as a knowledge base for flood risk assessment in urban area. Journal of Novel Applied Sciences, 2(8): 269-272. http://jnasci.org/wpcontent/uploads/2013/08/269-272.pdf

Nikolaou I, Evangelinos K, Filho WL. 2014. A system dynamic approach for exploring the effects of climate change risks on firms' economic performance. Journal of Cleaner Production, 103: 499-506.

DOI: https://doi.org/10.1016/j.jclepro.2014.09. 086

OCHA (Cartographer). 2014. Côte d'Ivoire: Zones à risques d'inondations et de choléra. OCHA.

Parkinson J. 2002. Urban drainage in developing countries - challenges and opportunities. waterlines, 20(4): 2-5. DOI: $\quad$ https://doi.org/10.3362/02628104.2002.018

Parkinson J, Tayler K, Mark O. 2007. Planning and design of urban drainage systems in informal settlements in developing countries. Urban Water Journal, 4(3): 137-149. DOI: $10.1080 / 15730620701464224$

Penning-Rowsell EC. 2015. Flood insurance in the UK: a critical perspective. WIREs Water, 2(6): 601-608. DOI: https://doi.org/10.1002/wat2.1104

RGPH. 2014. Recensement général de la population et de l'habitat 2014: principaux résultats préliminaires (1st ed). Institut National de la Statistique: Abidjan, Côte d'Ivoire.

Sané OD, Gaye AT, Diakhaté M, Aziadekey M. 2015. Social Vulnerability Assessment to Flood in Medina Gounass Dakar. Journal of Geographic Information System, 7: 415-429. DOI: http://dx.doi.org/10.4236/jgis.2015.7403 3

Soro N, Ouattara L, Dongo K, Kouadio Ek, Ahoussi Ek, Soro G, Oga Ms, Savane I, Biemi J. 2010. Déchets municipaux dans le District d'Abidjan en Côte d'Ivoire: 
sources potentielles de pollution des eaux souterraines. Int. J. Biol. Chem. Sci., 4(6): 2203-2219. DOI: http://dx.doi.org/10.4314/ijbcs.v4i6.6495 2.

Statistics Canada. 2010. Survey Methods and Practices (1st ed). Statistics Canada: Ottawa, Ontario.

Sultan B, Janicot S. 2000. Abrupt shift of the ITCZ over West Africa and intraseasonal variability. Geophysical Research Letters, 27(20): 3353-3356. DOI: https://doi.org/10.1029/1999GL011285

Surminski S, Eldridge J. 2015. Flood insurance in England - an assessment of the current and newly proposed insurance scheme in the context of risingflood risk. Flood Risk Management, 10(4): 415-435. DOI: 10.1111/jfr3.12127

Temgoua E, Ngnikam E, Ndongson B. 2009. Drinking water quality: stakes of control and sanitation in the town of Dschang -
Cameroon. Int. J. Biol. Chem. Sci., 3(3): 441-447. DOI: http://dx.doi.org/10.4314/ijbcs.v3i3.4534 6.

Tingsanchali T. 2012. Urban flood disaster management. Procedia Engineering, 32: 25-37.

DOI: 10.1016/j.proeng.2012.01.1233

UN-Habitat. 2008. The State of African Cities 2008: A framework for addressing urban challenges in Africa. UN-Habitat, Nairobi.

UNISDR. 2002. Guidelines for Reducing Flood Losses (1st ed). United Nations: New York.

WHO. 2014. WMO Disaster Risk Reduction Work Plan ( 2012-2015) Updated as of : 21 March 2014. World Meteorological Organization, Geneva.

Zhou Q. 2014. A Review of Sustainable Urban Drainage Systems Considering the Climate Change and Urbanization Impacts. Water, 6(4): 976-992. DOI: 10.3390/w6040976. 